\title{
A Geographical Study of the Ground Realities of Rural Safety Net in India: A village level study of MGNREGS
}

\section{Sarmistha Saha}

Department of Geography, Michael Madhusudan Memorial College, Durgapur, West Bengal, India

Corresponding author: sarmis2008mailbox@gmail.com

\begin{abstract}
Rural safety nets are indispensable ingredients of boosting economy of a developing country like India. Mahatma Gandhi National Rural Employment Guarantee Scheme (MGNREGS) is one of the most discussed safety net of the vast Indian subcontinent. NREGA act was passed by Union Government in 2005 which was later renamed as Mahatma Gandhi National Rural Employment Guarantee Act (MGNREGA) in year 2009. This Act results for the initiation of MGNREGS which came into existence on February 2, 2006. It was implemented in a phase wise manner. At first stage, 200 most backward districts of the country were covered, phase II included 130 additional districts and the final phase covered the remaining rural districts of the country. The spread and provisions of MGNREGS has made the scheme a pillar of Indian rural development. This is the landmark scheme of Indian Government which provides employment to the job seekers with a right based approach. Though the initial aim of this scheme was to provide employment to the unemployed rural youth, a strategy of sustainable livelihood is hidden under the policy. Much highlight has been given to the employment generation aspect of the scheme, as this was the prime focus of the Act. Financial year 2015-2016 accounts for the generation of 286497320 employment days in West Bengal in total with 9157780 MGNREGS workers. The aspect of generation of common property resources through MGNREGS is not much discussed and evaluated by the researchers. The quality and sustainability of rural Common Property Resources (CPRs) is significant for generating sustainable rural livelihood. This paper provides an attempt to see the realities of MGNREGS generated CPRs on an empirical basis. The gap of theoretical overview and real implementation is evaluated in this paper with empirical observation.
\end{abstract}

Keywords: MGNREGS, MGNREGA, ndian rural development, Common Property Resources

The most discussed rural safety net of contemporary Indian economy is Mahatma Gandhi National Rural Employment Guarantee Scheme (MGNREGS) for aiming to achieve sustainable rural development through the ideology of inclusive development. "While a number of rural employment programmes have been initiated in the past by the government, MGNREGS is unique in the sense that it provides a legal guarantee of employment to the targeted population, which is unlike any other centrally sponsored scheme. It places a judicially enforceable obligation on the state and gives bargaining power to those covered under the Act" (Dey et al. 2006). This scheme aims at generating employment days for unemployed rural Indians and at the same time aims at creating sustainable livelihood through the generation of common property resources. "MGNREGA is an example of the quantitative and qualitative difference experienced in a household because of the source through which the income flows in. If it is through the women, it enhances opportunities for their children, in turn positively affecting intergenerational change." (Sharma, 2011). Hirway, Saluja, and Yadav argued that "the role of any employment guarantee program is much more than guaranteeing work to the poor, because guarantee alone will have limited impact on employment generation in the economy." More than a decade has been passed after legislation of NREGA Act. In this time span, a variety of research has been done on 
various aspects of MGNREGS. Yet, there is a dearth of literature focussing on the aspects of common property resources generated by MGNREGS in rural India. The basic principle of the scheme is the generation of guaranteed employment in the whole country through a homogeneously regulated framework. Keeping the factors of variations as constant for entire state, the regional heterogeneity keeps the door open for further discussion and study carried on micro levels. This micro-level study has identified the ground realities of MGNREGS generated Common Property Resources (CPRs) and the way for optimum utilization and conservation of those CPRs in the study area.

\section{Methodology}

Selection of the study area: The field area selected is Amlajora village of Kanksa Block in Bardhaman district of West Bengal, India. This selection is based on the process of filtering through four indicators. In brief, the process of the Selection of Study area is as follows:

Burdwan district is selected for its good performance in MGNREGS in past years. At first step, a block wise analysis has been done based on the total person days generated through MGNREGS in financial year 2014-2015. Rank has been given accordingly with. (highest number of person days given rank 1 . To confirm the selection of the block, a Gram Panchayat (GP) level analysis has been done based on the same procedure and the Panchayats of Kanksa block was showing good performance in generating good number of person days through MGNREGS. So, Kanksa block was selected. From the selected block, a G.P. level analysis has been done based on following four indicators:

- Indicator-I is the number of total person days generated through MGNREGS in year 20142015. This indicator is selected to understand the extent of work done in the study area.

- Indicator-II is the total number of works generated through MGNREGS. Though this is not a good indicator to understand the spread of work because of the diversified nature of MGNREGS work offered in the village area, still this indicator is selected to understand the coverage of work to fulfil the objectives of the research.
- Indicator-III is the households got promised 100 days of work through MGNREGS in financial year 2014-2015. The questionnaire of the survey relates the questions regarding conservation part apart from the income generation aspects. So, this indicator is taken to get the response from those who have got full number of workdays and their response related to conservation.

- Indicator-IV is the average number of person days generated per work through MGNREGS in financial year 2014-2015. This is a proxy indicator to understand the intensity of work per rural asset.

Based on the above mentioned indicators, two Panchayats are showing good results. Amlajora and Bankati, both have got a cumulative rank value of 8 . (Here, lowest value means the highest performance). From these two, Amlajora has been selected for field work. This selection is Random.

\section{Data Base and Methodology}

This study relates the following methodologies of research:

(i) Obtaining secondary data from the website of MGNREGS.

(ii) Determining the area of field work through the analysis of secondary data.

(iii) Pilot survey of the village to determine the number of respondents and ground truth verification of MGNREGS created common property resources in the field area.

(iv) Frming of survey questionnaire.

(v) house listing and modification of survey questinaire as per responses.

(vi) GPS survey.

(vii) Respondents survey.

(vii) Focussed Group Discussion. (Those who are the nearest residents of MGNREGS generated CPRs and who have done the MGNREGS work for more than 40 days in finnacial year 2014-2015 are the members of the focussed group.)

(viii) analysis of the data.

The data base of the study refers to the website of MGNREGS, www.nrega.nic.in for secondary data 
Table 1: Calculation of Ranks Based on the Selected Indicators

Country: India

State: West Bengal

District: West Bardhaman

Block: Kanksa

\begin{tabular}{|c|c|c|c|c|c|c|c|c|c|}
\hline & Indicator-I & & Indicator -II & & Indicator - III & & Indicator - IV & & \\
\hline 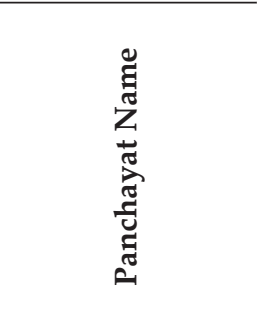 & 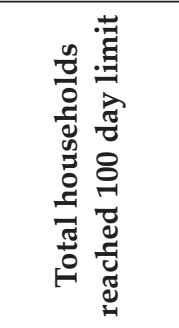 & こ & 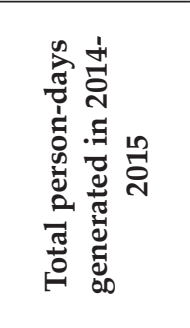 & $\underset{\Xi}{\Xi}$ & 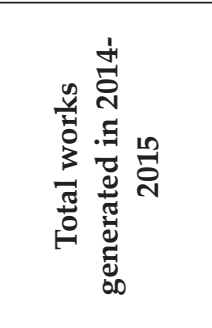 & 气 & 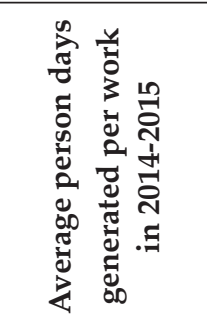 & 䒕 & 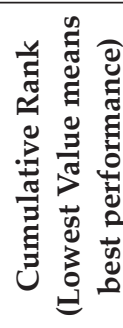 \\
\hline Amlajora & 404 & 1 & 272288 & 1 & 1264 & 5 & 215.42 & 1 & 8 \\
\hline Bonkati & 373 & 2 & 210883 & 2 & 2542 & 2 & 82.96 & 2 & 8 \\
\hline Gopalpur & 73 & 5 & 116489 & 3 & 2928 & 1 & 39.78 & 7 & 16 \\
\hline Molandighi & 125 & 3 & 107896 & 5 & 1939 & 3 & 55.65 & 6 & 17 \\
\hline Kanksa & 72 & 6 & 103232 & 6 & 1259 & 6 & 82 & & 18 \\
\hline Trilokchandrapur & 35 & 7 & 108569 & 4 & 1549 & 4 & 70.09 & 5 & 20 \\
\hline Bidbihar & 81 & 4 & 93425 & 7 & 1177 & 7 & 79.38 & 4 & 22 \\
\hline
\end{tabular}

Source: www.nrega.nic.in

and primary data is obrtained from the field survey of the selected village.

\section{RESULTS AND DISCUSSION}

In relation to the study mentioned above there exists marked variation regarding the promise of the scheme and ground realities of it. This study relates following observations:

1. Uneven distribution of resources: It has been found by the field survey that CPRs created by MGNREGS are unevenly distributed over the village space. This is mostly because of the limitation of the available physical space. CPRs listed in MGNREGA law requires much physical space to construct, which is a hindrance for even distribution. Another factor revealed by FGD is, CPRs like roads are created and re-builded over the years nearest to the politically and socially influential people of the village. Some village roads have shown sudden end which was not clarified by village authority. This finding is in compliance with the findings of Verma and Shah (2012) .According to them "an indifferent block and district administration caused long delays in the works approval and wage payment processes and a poor performance in both quantity of employment generated and quality of assets; leaving the village communities feeling helpless, dejected and cynical".

Table 2: Response Related to duplication of MGNREGS work (obtained by FGD)

\begin{tabular}{|c|c|c|}
\hline Reason for Duplication & Frequency & $\begin{array}{l}\% \text { of fre- } \\
\text { quency to } \\
\text { total }\end{array}$ \\
\hline Physical space is less & 51 & 32.07 \\
\hline $\begin{array}{l}\text { Authority does not take } \\
\text { villagers opinion about CPR } \\
\text { creation }\end{array}$ & 59 & 37.11 \\
\hline $\begin{array}{l}\text { Misuse of fund by village } \\
\text { authority }\end{array}$ & 13 & 8.18 \\
\hline $\begin{array}{l}\text { CPRs are of poor quality so they } \\
\text { need reconstruction }\end{array}$ & 27 & 16.98 \\
\hline Does not have any opinion & 9 & 5.66 \\
\hline Total & 159 & 100 \\
\hline
\end{tabular}

Source: Field survey, October 2016-December 2016.

The area of concentration of MGNREGS work in the study area is the southern 
part of the village. Other parts are merely experienced any kind of development through MGNREGS.

2. Poor quality of the resources: MGNREGS created CPRs in the study area are not built by good quality material and they are not done thinking about the long term benefits of the villagers. Roads are of poor quality, plantation is inadequate and ponds are often dried at summer season because of their limited depth. It seemed that the village authority is keener to generate employment days through resource creation rather to create rural resources on a sustainable basis. Ambastha et al. (2008) has pointed out the poor quality of assets created under MGNREGS three years after the legislation and the same tradition has found to be continued in the study area.

Table 3: Response Related To Restoration of MGNREGS Created Assets

\begin{tabular}{ccc}
\hline Response & Frequency & Percent \\
\hline YES & 68 & 33.8 \\
NO & 132 & 65.7 \\
No Response & 1 & .5 \\
\hline Total & $\mathbf{2 0 1}$ & $\mathbf{1 0 0 . 0}$ \\
\hline
\end{tabular}

Source: Filed Survey, September 2015-December 2016.

Table 4: Response Regarding No Conservation of MGNREGS Created CPRs

\begin{tabular}{lcc}
\hline $\begin{array}{l}\text { Reason for not taking any } \\
\text { attempt to preserve CPRs }\end{array}$ & Frequency & Percent \\
\hline $\begin{array}{l}\text { Not requirement is placed by } \\
\text { MGNREGS }\end{array}$ & 37 & 28.03 \\
$\begin{array}{l}\text { Assets are built far off from the } \\
\text { residence }\end{array}$ & 9 & 6.82 \\
$\begin{array}{l}\text { Respondent does not feel the need } \\
\text { No idea about restoration }\end{array}$ & 39 & 29.55 \\
$\begin{array}{l}\text { Problematic to manage } \\
\text { Restoration is Panchayat }\end{array}$ & 19 & 14.39 \\
$\begin{array}{l}\text { responsibility } \\
\begin{array}{l}\text { Discouragement by village } \\
\text { authority }\end{array}\end{array}$ & 5 & 3.79 \\
$\begin{array}{l}\text { No time to do restoration work } \\
\begin{array}{l}\text { Presently no assets built/work } \\
\text { done so nothing to preserve }\end{array}\end{array}$ & 3.79 \\
\hline \begin{tabular}{l} 
Total \\
\hline
\end{tabular} & $\mathbf{1 3 2}$ & $\mathbf{1 0 0 . 0}$ \\
\hline
\end{tabular}

Source: Filed Survey, September 2015-December 2016.
3. Poor management of CPRs: In the field survey, it has been found that minimal or no effort is taken to manage or preserve the newly created CPRs. The lack of awareness about the usefulness of CPRs in the long run is mainly responsible for this. Another psychology related to these CPR followed by the principle of "Tragedy of the Commons". While villagers are keen to get the benefits, they are not ready to take care of the resources, rather they think that preservation is the responsibility of village authority. A close talk with village officials revealed that they visualize the aspect of preservation and management as Villager's responsibility. This conflict has led to the poor management of the resources in study area. The study of Singh and Modi (2010) supports this finding with a view that the rural communities are either 'incapable' or 'unwilling' to manage the MGNREGS created assetsSimilarly, Kumar and Chandra (2010) argued about the special provisions for the Gram Panchayats to commence repair and maintenance work on a regular basis.

Table 5: Ground Realities of MGNREGS Generated CPRS

\begin{tabular}{|c|c|c|}
\hline $\begin{array}{l}\text { Problems Related With } \\
\text { MGNREGS Generated } \\
\text { CPRs }\end{array}$ & $\begin{array}{c}\text { Frequency of } \\
\text { Respondents } \\
\text { reported } \\
\text { incident }\end{array}$ & $\begin{array}{l}\text { Percentage } \\
\text { of } \\
\text { respondents }\end{array}$ \\
\hline $\begin{array}{l}\text { CPRs are unevenly } \\
\text { distributed so not equally } \\
\text { accessible for all }\end{array}$ & 35 & 17.41 \\
\hline Roads are not of good quality & 38 & 18.91 \\
\hline $\begin{array}{l}\text { Ponds dries up in summer } \\
\text { season }\end{array}$ & 33 & 16.42 \\
\hline CPRs are poorly managed & 29 & 14.43 \\
\hline $\begin{array}{l}\text { Heightening and deepening } \\
\text { of embankment is not at } \\
\text { optimum level }\end{array}$ & 13 & 6.47 \\
\hline $\begin{array}{l}\text { Quality of earthen } \\
\text { embankment is not good }\end{array}$ & 41 & 20.40 \\
\hline $\begin{array}{l}\text { Number of plantation } \\
\text { grounds are less }\end{array}$ & 9 & 4.48 \\
\hline $\begin{array}{l}\text { No opinion about } \\
\text { MGNREGS created CPRs }\end{array}$ & 3 & 1.49 \\
\hline Total & 201 & 100 \\
\hline
\end{tabular}

Source: Filed Survey, September 2015-December 2016. 
4. Duplication of work: To generate CPRs on a regular basis, village authorities had made the same CPRs again and again irrespective of the need. For example, because of the poor maintenance of plantation ground, trees often survives less and in next monsoon, authorities decide to plant the trees again in the same ground for generating employment under MGNREGS. A road in the study area has been builded and rebuilded again and again to generate mere employment. This is because of the (a) lack of the ability of village authority to conceptualize about more useful CPRs (b) lack of administrative staffs in the Panchayat and (c) urgent need to generate employment within a limited time span (authority is responsible to manage and send data regarding MGNREGS to MoRD regularly.

\section{CONCLUSION}

The observations of the study may be of interest of Indian policy makers, as this field study provides a detailed attempt to find out the gendered variations of responses related to the CPRs created by MGNREGS in rural West Bengal. Undoubtedly MGNREGS has contributed greatly in last 11 years to the lives of the rural poor. Still more study is needed to understand the detailed aspects of livelihood change regarding this safety net. Though temporal progress is seen in terms of MGNREGS implementation in West Bengal but the goal of 100 days of promised employment is far to achieve. This is one of the major drawbacks of the scheme implementation in west Bengal. It is also suggested that apart from mere fulfilment of the one third of women beneficiaries, the emphasis should be given on fulfilment of promised employment days to rural women together with encouragement of women to bring them in the workforce. Participation of more women in the workforce will enhance the generation of more CPRs which in turn will accelerate the more utilization of rural CPRs.

In this way more ease of livelihood could be achieved. Further, increased participation will enhance more employment, more employment will create or modify more rural assets, will generate more income and in turn, generate more savings. These enhanced outcomes like employment, savings, income and rural assets can lead to a sustainable village economy in West Bengal. The aspect of sustainable CPR generation is highly related with the aspect of generation of employment days. While seeing the gendered utilization of MGNREGS generated CPRs in the selected study area through the lense of reality based survey, many shortcomings of the scheme implementations are found.

This study indicates that there is a wide gap between the promise of this much discussed safety net and its implementation in the ground level. The productive value of MGNREGS created CPRs can be enhanced with efficient long term planning. Awareness generation among villagers and mass participation in CPR conservation process could be the tool for generating sustainable livelihood in rural India.

\section{REFERENCES}

Ambasta, P., Vijay Shankar, P.S. and Shah, M. 2008. Two Years of NREGA: The Road Ahead. Economic and Political Weekly, 43(8): 41-50.

Dey, N., Drèze, J. and Khera, R. 2006. Employment guarantee act: A primer. New Delhi: National Book Trust.

Dreze, J. 2007. NREGA: Dismantling the contractor raj. The Hindu, Nov 20.

Hirway, I., Saluja, M.R. and Yadav, B. 2010. Employment guarantee programme and pro-poor growth: The study of a village in Gujarat. New Delhi: Academic Foundation.

Kumar, A. and Chandra, G. 2010. Effectiveness and ownership of irrigation assets created under MNREGA and labor market dynamics in Bihar. (MTS report). Institute of Rural Management, Anand.

Shah, M. 2009. Taking goals of NREGA-I forward. The Hindu.

Sharma, A. 2011. Sharing Innovative Experiences: Successful social protection floor experiences. UNDP Global SouthSouth Development Academy ILO, 18: 271-290.

Singh, A. and Modi, R. 2010. Effectiveness and ownership of assets created under NREGS in Rajasthan. (MTS Report) Institute of Rural Management, Anand.

Verma, S. and Shah, T. 2012. Water Policy Research: Highlight beyond digging and filling holes: Lessons from case studies of best-performing MGNREGA water assets. Accessed from www.iwmi.org/iwmi-tata/apm2012; on 26.09.2018. 
